\title{
ANDROGÊNESE: UMA ROTA ALTERNATIVA NO DESENVOLVIMENTO DO PÓLEN
}

\author{
ANDROGENESIS: AN ALTERNATIVE ROUTE IN THE POLLEN DEVELOPMENT
}

\author{
Eliane Kaltchuk-Santos ${ }^{1}$ Maria Helena Bodanese-Zanettini ${ }^{2}$
}

\section{- REVISÃO BIBLIOGRÁFICA -}

RESUMO

A androgênese é o fênomeno no qual um grão de pólen é capaz de alterar sua rota de desenvolvimento e originar um esporófito haplóide. Este processo ontogenético alternativo ainda é pouco conhecido, apesar de sua potencialidade tanto para estudos básicos como àqueles aplicados para melhoramento de plantas. $O$ presente artigo tem como propósito revisar os fatores envolvidos no desvio da via gametofítica normal $e$ os mecanismos fundamentais na indução da embriogênese do pólen.

Palavras-chave: embriogênese do pólen, divisão simétrica, pólen $P$, estresse, cultura de anteras.

\section{SUMMARY}

Androgenesis is a phenomenon in which pollen grain changes its developmental pathway giving rise to haploid sporophyte. This alternative ontogenetic process is still not completely understood despite of its potencial to basic and applied studies, including crop improvement. The present article has the purpose of reviewing the factors related to the deviation of normal gametophytic route and the fundamental mechanisms of pollen embryogenesis induction.

Key words: pollen embryogenesis, symmetrical division, $P$ pollen, stress, anther culture.

\section{INTRODUÇÃO}

A possibilidade do uso da haploidia para estudos básicos e aplicados de genética, melhoramento, evolução e biologia floral vem há bastante tempo despertando o interesse na obtenção de metodologias eficientes para a produção de plantas haplóides.

Nas últimas décadas, inúmeros estudos vêm sendo feitos visando à regeneração de plantas haplóides a partir da cultura in vitro de células gametofíticas. Atualmente, a cultura de anteras, através do processo de androgênese, tem sido a técnica mais empregada para a obtenção de haplóides.

Uma planta haplóide tem somente metade do patrimônio genético sendo, portanto, estéril. A duplicação de seu número cromossômico de maneira espontânea, ou induzida pela aplicação de colchicina, recupera a condição diplóide e restaura a fertilidade. Esta planta, chamada de duplohaplóide será totalmente homozigota, uma vez que cada cromossomo terá sua cópia exata (MORAESFERNANDES, 1990).

A homozigose alcançada mediante a haplodiploidização torna a cultura de anteras uma interessante ferramenta para o melhoramento vegetal. No sistema convencional de melhoramento de autógamas, onde o método de cruzamentos é usado, são necessários de 7 a 8 ciclos de autofecundação para estabilizar o genótipo pela fixação de genes em homozigose. Além de ser um processo demorado e trabalhoso, a eficiência da seleção nas primeiras gerações de autofecundação é

\footnotetext{
${ }^{1}$ Biólogo, Doutor, Professor Adjunto, Departamento de Genética, Universidade Federal do Rio Grande do Sul (UFRGS), CP 15053, 1501-970, Porto Alegre, RS, Brasil. E-mail: ekalt@if.ufrgs.br. Autor para correspondência.

${ }^{2}$ Biólogo, Doutor, Professor Titular, Departamento de Genética, UFRGS.
} 
muito baixa devido, principalmente, à ocorrência de alelos dominantes em heterozigose.

A vantagem mais evidente no sistema de duplo-haplóides é a diminuição no tempo necessário para o estabelecimento de estoques puros de novas cultivares, uma vez que linhagens homozigotas são obtidas em uma única geração em culturas anuais. Este sistema representa para os programas de melhoramento uma economia não só em relação ao tempo como também quanto aos custos de produção de novas linhagens (MORAES-FERNANDES, 1990).

Ao eliminar o mascaramento causado pela heterozigose, a produção do duplo-haplóide traz outra vantagem, que é a de ampliar a eficiência de seleção, tanto para caracteres qualitativos como quantitativos, facilitando, portanto, a identificação de genótipos superiores.

A cultura de anteras em plantas alógamas, altamente heterozigotas, como o milho e o aspargo, permite a produção de linhagens puras que podem ser utilizadas como progenitoras no desenvolvimento de cultivares híbridas (MORAESFERNANDES $\boldsymbol{e t}$ al., 1999).

As aplicações dos haplóides androgenéticos não se limitam às acima referidas; estes podem ser empregados em trabalhos envolvendo a obtenção de mutantes, na fusão somática e, ainda, como alvo para transferência de genes (ATANASSOV et al., 1995).

A técnica de cultura de anteras vem sendo usada rotineiramente em programas de melhoramento de várias famílias importantes como os cereais, as crucíferas e as solanáceas (MORAESFERNANDES $\boldsymbol{e} \boldsymbol{t} \boldsymbol{a l}$., 1999). A cultivar BR-43 de trigo foi produzida no Brasil através desta metodologia (CAETANO \& MORAESFERNANDES, 1992).

A presente revisão literária tem como objetivo reunir informações sobre o processo androgenético, os fatores envolvidos em sua indução e sua aplicabilidade através da técnica de cultura de anteras, tornando-se uma fonte de fácil consulta por parte de estudantes, docentes e pesquisadores.

\section{Pólen: estratégias de deSEnVolvimento}

GUHA \& MAHESHWARI (1964) ao inocularem anteras de Datura innoxia em meio de cultura verificaram que alguns grãos de pólen passavam por divisões mitóticas sucessivas tornando-se multicelulares. Tais grãos sofriam ruptura da exina e liberação da massa celular havendo, então, a formação de embrióides. Análises citológicas das plântulas evidenciaram número haplóide de cromossomos $(n=12)$. A este fenômeno da formação de uma planta haplóide a partir de um grão de pólen, dá-se o nome de "androgênese", "embriogênese do pólen", ou ainda, "embriogênese haplóide" (RAGHAVAN, 1987).

Para entender melhor como se dá esta alteração na programação genética do micrósporo, é interessante que, primeiramente, sejam feitas considerações quanto a ontogenia normal dos grãos de pólen.

A formação do pólen compreende dois eventos: a microsporogênese e a microgametogênese. $\mathrm{O}$ processo da microsporogênese começa com a meiose e termina com a formação de um micrósporo haplóide polarizado (TOURAEV et al., 1997). A partir deste ponto, o micrósporo poderá seguir sua rota normal de desenvolvimento (via gametofítica) ou, alternativamente, uma rota androgenética (via esporofítica) dependendo das condições do ambiente.

\section{MiCROGAMETOGÊNESE: NORMAL DO PÓLEN}

O micrósporo jovem, após sua liberação da tétrade, possui um grande núcleo central, citoplasma rico em ribossomos e com numerosos pequenos vacúolos (SANGWAN \& CAMEFORT, 1982) (Figura 1A-I). Ao longo do tempo ocorre a coalescência destes vacúolos resultando na formação de um único vacúolo grande e central e, conseqüentemente, no deslocamento do núcleo para junto da parede do micrósporo (SAX \& EDMONDS, 1933) (Figura 1A-II).

Esta migração do núcleo constitui uma etapa chave da microgametogênese, uma vez que, em seguida se dá a primeira divisão mitótica (Figura 1A-III). A polarização do núcleo acarreta assimetria do fuso mitótico e, conseqüentemente, distribuição desigual do citoplasma nas células-filhas, células vegetativa e generativa (SAX, 1935; LA COUR, 1949). As células-filhas serão estrutural e funcionalmente diferentes, embora possuam um mesmo conteúdo genético (Figura 1A-IV).

A segunda mitose do pólen envolve apenas o núcleo generativo, enquanto a célula vegetativa permanece quiescente. Esta divisão dá origem a duas células alongadas e em forma de meia-lua, denominadas células espermáticas. Portanto, o gametófito maduro é constituído por três células, a vegetativa e as duas gaméticas.

\section{ANDROGÊNESE: ROTA ALTERNATIVA DO PÓLEN}

Análises citológicas da segmentação inicial de micrósporos oriundos da cultura de 


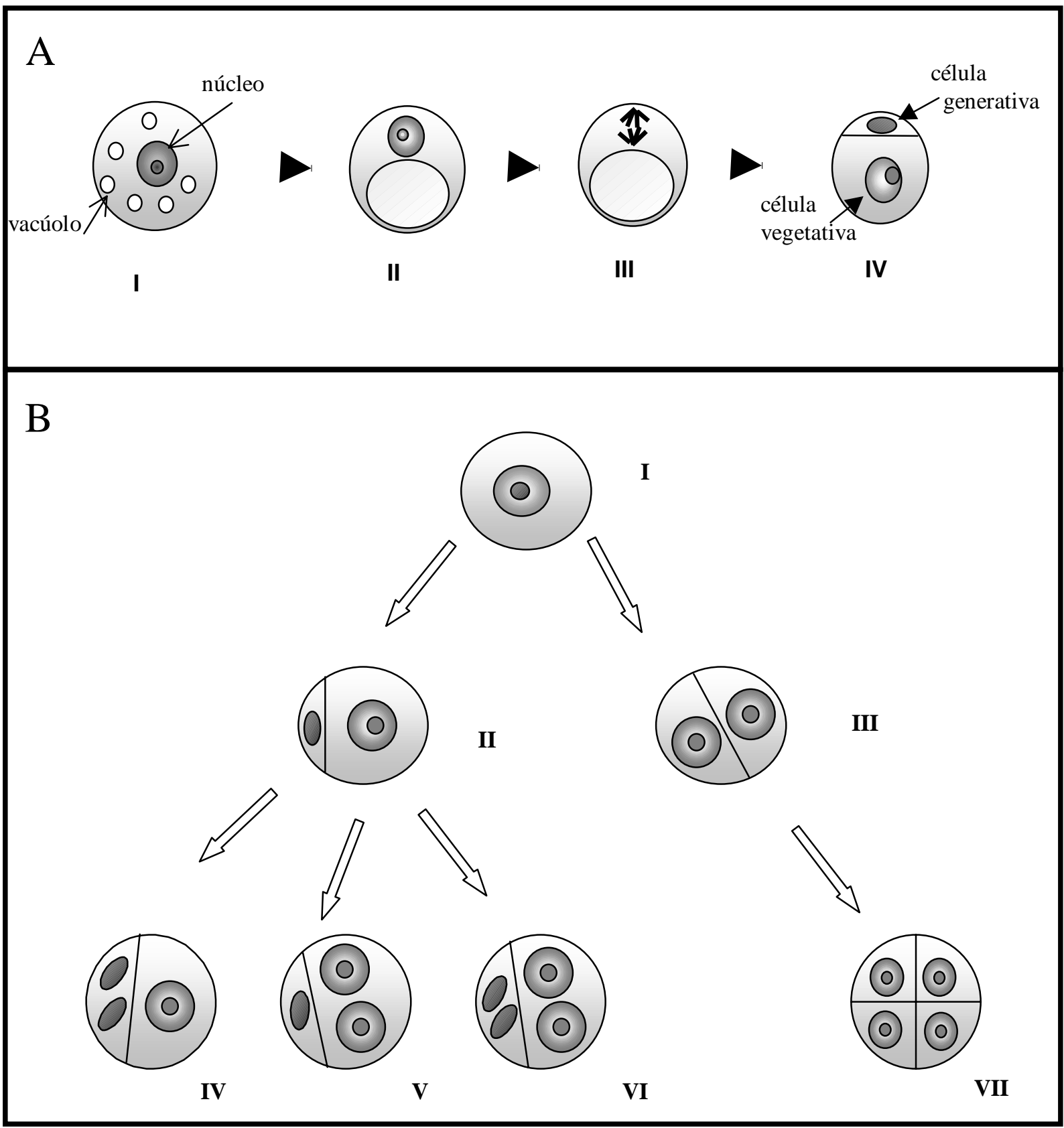

Figura 1 - A . Esquema simplificado da microgametogênese: I. micrósporo jovem com núcleo central e presença de pequenos vacúolos; II. coalescência dos vacúolos pequenos resultando na formação de um único maior que empurra o núcleo para a periferia da célula; III. mitose assimétrica; IV. pólen binucleado apresentando duas células estrutural e funcionalmente diferentes (células vegetativa e generativa). B. Rotas de segmentação do micrósporo in vitro: I. micrósporo jovem; II. pólen binucleado assimétrico; III- pólen binucleado simétrico; IV. Rota I - apenas a célula generativa segue dividindo; V. Rota II - apenas a célula vegetativa segue dividindo; VI. Rota III- ambas as células, vegetativa e generativa dividem; VII. Rota IV - as duas células idênticas seguem dividindo.

anteras, em várias espécies, mostram a existência de quatro rotas de androgênese in vitro (SUNDERLAND \& DUNWELL, 1974; RASHID \& STREET, 1974 - ver figura 1B):

Rota I - o micrósporo segue seu curso normal, passando pela divisão assimétrica e a diferenciação celular, para formar uma célula generativa e uma vegetativa. Mas, apenas a célula generativa continua dividindo-se e é envolvida na embriogênese (Figura 1B-IV). Esta rota é pouco observada sendo, porém, uma via freqüente em Glycine max (KALTCHUK-SANTOS et al., 1997)

Ciência Rural, v. 32, n. 1, 2002. 
e aquela predominante em Hyocyamus niger (RAGHAVAN, 1978).

Rota II - nesta rota, assim como na anterior, a primeira divisão mitótica e a diferenciação celular são normais. A célula generativa não é funcional e degenera-se rapidamente, ou após uma ou duas divisões. Apenas a célula vegetativa participa na formação do embrião (Figura 1B-V). Esta via é comumente encontrada em Nicotiana tabacum (HORNER \& STREET, 1978), em Hordeum vulgare (SUNDERLAND et al., 1979) e Triticum aestivum (REYNOLDS, 1993), entre outros.

Rota III - a primeira divisão é assimétrica e ambas as células, vegetativa e generativa, continuam a dividir-se e participam no desenvolvimento do embrião androgenético (Figura 1B-VI). Em Datura innoxia (SUNDERLAND, 1974), Hordeum vulgare (SUNDERLAND et al., 1979), Solanum carolinense (REYNOLDS, 1986) e Glycine max (KALTCHUK-SANTOS et al., 1997) foi verificada a ocorrência desta rota.

Rota IV - o micrósporo sofre uma divisão simétrica cujas duas células-filhas idênticas com características do tipo vegetativo contribuem para o desenvolvimento do esporófito haplóide (Figura 1BVII). Tal via é descrita em várias espécies como Nicotiana tabacum (RASHID \& STREET, 1974), Datura innoxia (SUNDERLAND, 1974), Hordeum vulgare (CHEN et al., 1984), Triticum aestivum (GRANDO, 1989) e Glycine max (KALTCHUKSANTOS et al., 1993).

Independentemente do padrão inicial de segmentação, o pólen sofre divisões tornando-se multicelular, e este tecido pode tomar duas possíveis direções: (1) formar um embrião globular que passa pelos estágios normais da embriogênese pósglobular; (2) proliferar e formar um calo que mais tarde se diferencia em plântulas, via embriogênese ou organogênese (BHOJWANI \& RAZDAN, 1983).

\section{A DIVISÃo SIMÉTRICA E A ANDROGÊNESE}

Apesar da existência documentada das quatro rotas de segmentação do micrósporo, acima relatadas, a rota IV tem sido apontada como sendo exclusivamente de caráter embriogênico.

Os primeiros estudos para investigar a origem dos embriões haplóides mostraram que dentre a população de pólens de uma antera, alguns possuíam dois núcleos idênticos devido à divisão simétrica, sendo estes potencialmente embriogênicos (NORREEL, 1970). Desde então, vários trabalhos têm mostrado uma correlação entre a frequiência de divisão simétrica e a freqüência de embriões haplóides, o que sugere que este tipo de mitose seria um sinal reconhecido pela célula para reativar o programa esporofítico (para revisão ver GRANDO \& MORAES-FERNANDES, 1997).

Em cultura de anteras de aspargo, PENG et al.(1997) constataram que a formação de calos, embriões e plântulas haplóides tem como prérequisito a ocorrência de divisão simétrica. Grãos de pólen cuja primeira mitose tenha sido do tipo assimétrica não sofrem divisões adicionais e, portanto, não tomam a via esporofítica. Vários outros estudos (FAN et al., 1988; ZAKI \& DICKINSON, 1990, 1991,1995) apóiam a hipótese de que a simetria na mitose do pólen é um ponto chave para que ocorra o desvio do programa gametofítico.

A mudança na ontogenia normal de um micrósporo para uma via esporofítica requer alterações profundas na morfogênese celular (IQBAL et al., 1994). Os microtúbulos que determinam a localização das organelas, incluindo o núcleo, estão necessariamente envolvidos em tais mudanças morfogenéticas. Assim, a reorganização dos microtúbulos é vista como uma condição necessária na alteração do padrão de desenvolvimento.

O pólen binucleado simétrico é formado após uma divisão equacional, cujo resultado são duas células idênticas do tipo vegetativo. Sua origem deve-se, basicamente, a não formação do vacúolo ou modificação no eixo de divisão da célula. Presumese que o potencial androgenético deste tipo de pólen deva-se à manutenção de determinantes esporofíticos (mRNA e ribossomos) em seu citoplasma. Desta forma, o pólen resultante de divisão simétrica poderia ser definido como uma estrutura embriogênica induzida (ZHAO et al., 1996).

\section{OS FATORES DE ESTRESSE NA INDUÇÃO ANDROGENÉTICA}

$\mathrm{Na}$ verdade, sabe-se pouco sobre os mecanismos de redirecionamento da ontogenia do gametófito masculino no sentido de formar uma célula embriogênica (GARRIDO et al., 1993), mas, os estudos têm mostrado que este redirecionamento necessita de um estímulo-sinal.

Segundo o modelo determinístico de dois pontos, proposto por GRANDO \& MORAESFERNANDES (1997), haveria dois momentos no qual o micrósporo poderia ter sua via ontogenética normal alterada, levando à aquisição do potencial androgenético. $\mathrm{O}$ primeiro ponto de alteração seria no início da meiose e o segundo durante o estádio 
uninucleado do pólen. Há evidências de que a eliminação das moléculas carreadoras de informações esporofíticas (mRNA, ribossomos e proteínas) deve ocorrer nestas duas etapas e qualquer anormalidade que impeça a correta eliminação destas moléculas acarretará a reativação do processo embriogênico.

Estudos indicam que a aplicação de fatores externos torna o micrósporo competente para a androgênese (REYNOLDS, 1997). O estresse parece ser $o$ sinal para iniciar o processo androgenético, uma vez que proteínas de estresse são detectadas durante a indução da embriogênese haplóide. Tais proteínas seriam responsáveis pela reprogramação da célula e pela proteção à condição estressante (KIVIHARJU \& PEHU, 1998).

Uma série de fatores de estresse aplicados in vivo ou in vitro tem sido identificados como capazes de disparar o processo esporofítico (IMMONEN \& ROBISON, 2000; SMYKAL \& PECHAN, 2000). Entre eles podem ser listados, choque térmico (calor ou frio), irradiação, agentes anti-mitóticos (colchicina), carência de nitrogênio, carência de carboidratos, incubação em solução de manitol (ver REYNOLDS, 1997 e MARDHORST $\boldsymbol{e}$ al., 1997).

O uso de fatores de estresse na indução da androgênese não é um fato recente. NITSCH \& NORREEL (1973) aplicaram pré-tratamento de frio em botões florais de Datura innoxia e constataram um aumento na freqüência de pólens com dois núcleos idênticos, bem como no número de embriões formados

O tratamento das anteras a baixas temperaturas, antes ou no início da cultura in vitro, tem como conseqüências para o grão de pólen a dissolução dos microtúbulos e alterações na distribuição do citoplasma e na divisão celular (RASHID, 1983). Portanto, é provável que o prétratamento de frio exerça seu efeito através de uma interferência precoce no estabelecimento da polaridade, resultando numa mudança na organização do fuso, com a formação de pólens binucleados simétricos (MAHESHWARI et al., 1980; RASHID, 1983).

Além do uso dos tratamentos de frio, a indução de mitose simétrica no micrósporo pode ser alcançada através do uso de colchicina. A colchicina é uma droga que se liga a heterodímeros $(\alpha-$ e $\beta$ tubulinas) inibindo a adição de dímeros aos microtúbulos, resultando na sua despolimerização e, impedindo assim, a progressão no desenvolvimento do pólen (ZHAO et al., 1996).

Uma série de estudos sobre o efeito do agente antimitótico colchicina na cultura de anteras e de micrósporos de Brassica napus mostrou que esta substância age como um promotor da androgênese; tratamentos com colchicina resultaram num aumento significativo no número de divisões simétricas, bem como, no número de embriões formados (ZAKI \& DICKINSON, 1990, 1991, 1995). Resultados semelhantes foram também obtidos por IQBAL $\boldsymbol{e t}$ al. (1994) e ZHAO et al. (1996) em Brassica, e por SZAKÁCS \& BARNABÁS (1995) em trigo.

Os resultados obtidos nos estudos acima apontam a colchicina como um promotor da androgênese através da reorganização do citoesqueleto. Entretanto, ZAKI \& DICKINSON (1995) argumentaram que, embora esta droga tenha potencialidade para induzir mitose simétrica, a sua capacidade em aumentar paralelamente a embriogênese ainda não estava claramente comprovada. De acordo com TOURAEV et al. (1996a), a simetria não é uma condição essencial para a aquisição da capacidade embriogênica.

Investigações utilizando estresses do tipo choque de calor (BINAROVA et al., 1997) e carência de sacarose (ZÁRSKÝ et al., 1995) na indução da androgênese, demostraram a presença de proteínas de choque térmico (HSPs). Foi verificada uma alta correlação entre a indução do desenvolvimento embriogênico e a presença de proteínas de choque térmico da classe da HSP70 (CORDEWENER et al., 1995).

O aparecimento de transcritos de HSPs pode ser usado como um marcador para estimar o nível de estresse necessário para induzir grãos de pólen jovens a alterar sua via de desenvolvimento, uma vez que a indução de androgênese não ocorre sem que haja a transcrição de genes de HSPs (SMYKAL \& PECHAN, 2000).

O uso combinado dos fatores, choque de calor e carência de sacarose, tem levado a acréscimos significativos na indução de embriogênese do pólen, tanto em tabaco como em trigo (TOURAEV et al., 1996a; TOURAEV et al., 1996b). Contudo, em triticale IMMONEN \& ROBISON (2000) testaram diferentes fatores de estresse e verificaram que, embora estes tenham sido capazes de melhorar a resposta androgenética, não foram capazes de induzir a androgênese nos genótipos mais recalcitrantes.

\section{O PÓLEN P E A COMPETÊNCIA ANDROGENÉTICA}

Um fenômeno aparentemente relacionado com a androgênese é o dimorfismo polínico, o qual se refere à população de micrósporos atípicos encontrados tanto em flores próximas ao estádio de maturação in situ, bem como, em anteras in vitro 
(SUNDERLAND \& WICKS, 1971). Estes grãos de pólen têm sido chamados de "pólens P" (HEBERLE-BORS \& REINERT, 1979), "pólens S" (HORNER \& STREET, 1978), ou ainda, "pólens E" (SUNDERLAND \& WICKS, 1969).

O dimorfismo pode ser constatado através da análise citológica de anteras, tendo sido demonstrada a existência de duas classes distintas de micrósporos quando coloridos com carmim, a saber, os normais e os do tipo P (SUNDERLAND, 1974). Análises ultraestruturais mostram que os micrósporos atípicos são menores, fracamente corados, podendo ser uni ou binucleados, com dois núcleos iguais ou desiguais. Sua exina é fina e o citoplasma atenuado com a presença de poucos ribossomos e mitocôndrias condensadas (SUNDERLAND, 1978; RASHID et al., 1981). Tais micrósporos podem representar, em algumas espécies, de $15 \%$ a $20 \%$ da população de pólens de uma antera, e encontram-se atrasados em relação à ontogenia dos normais (SUNDERLAND, 1974).

O dimorfismo do pólen já foi relatado em várias espécies, como por exemplo, Tradescantia bracteata (LA COUR, 1949), Paeonia hybrida (SUNDERLAND, 1974), Hordeum vulgare (DALE, 1975), Nicotiana tabacum (HORNER \& STREET, 1978), Triticum aestivum (GRANDO, 1989) e Glycine max (KALTCHUK-SANTOS et al., 1993).

Na natureza, o pólen $\mathrm{P}$ é um gametófito não funcional e pode ser considerado como um tipo de macho-esterilidade (HEBERLE-BORS, 1982), porém em condições adequadas de cultura in vitro ele pode seguir a via embriogênica ao invés da gametofítica.

Em algumas espécies como o tabaco, a freqüência de grãos de pólen embriogênicos varia de acordo com as condições de cultura da planta doadora, o que poderia indicar que há uma certa prédeterminação envolvendo o dimorfismo do pólen. Portanto, os micrósporos exibiriam sua tendência androgenética ainda na planta doadora, antes da cultura in vitro (BONET et al., 1998).

A formação do pólen do tipo P se dá antes ou durante o evento meiótico, possivelmente devido a falhas na eliminação de determinantes esporofíticos, podendo ser influenciada por fotoperíodo e temperatura (HEBERLE-BORS, 1982).

A estreita similaridade dos pólens $\mathrm{P}$ com micrósporos jovens, no que concerne à exina fina $\mathrm{e}$ ao citoplasma esparso, sugere que os pólens atípicos estejam num estado reprimido e indeterminado de diferenciação, evidenciando um potencial embriogênico.
Em Paeonia hybrida, os pólens do tipo $\mathrm{P}$ observados in situ são apontados como os responsáveis pela formação de embrióides em cultura de anteras (SUNDERLAND \& DUNWELL, 1974). Estes pólens também foram considerados embriogênicos em cevada, uma vez que houve correlação entre a freqüência de estruturas androgenéticas obtidas in vitro e a freqüência de micrósporos atípicos in situ. Vários autores referem este tipo de correlação, em apoio à hipótese de que estes grãos atípicos possuam um potencial embriogênico adquirido ainda durante a meiose (DALE, 1975; HORNER \& STREET, 1978; HORNER \& MOTT, 1979; HEBERLE-BORS \& REINERT, 1979, 1980, 1981).

Existem, porém, controvérsias quanto à real importância do dimorfismo polínico na indução da androgênese. Como explicar situações em que certas plantas, como a Datura innoxia, não exibam dimorfismo mas tenham taxas de indução haplóide consideravelmente altas?

Questionamentos também surgem quando, em certas espécies, não é encontrada correlação entre a frequiência de pólens $\mathrm{P}$ in situ e a freqüência de estruturas androgenéticas formadas in vitro.

A existência de vários trabalhos que apóiam a teoria da embriogenicidade do pólen $\mathrm{P}$ e outros que a refutam, leva a acreditar que, embora este tipo de pólen possa realmente responder pela indução haplóide, provavelmente, ele não seja a única fonte androgenética.

\section{CONCLUSÃO}

A técnica de cultura de anteras/micrósporos, visando à produção de haplóides, vem sendo amplamente empregada na obtenção de novas cultivares em várias plantas de interesse agronômico. Na China, ainda na década de 70 , foram lançadas as primeiras cultivares de fumo, arroz e trigo obtidas mediante o cultivo de anteras (MORAES-FERNANDES $\boldsymbol{e t}$ al., 1999).

O interesse no uso do sistema de duplohaplóides androgenéticos na obtenção de linhagens puras pode ser justificado por benefícios tais como a redução de tempo e de custos, a maior variância genética, a melhor eficiência na seleção e, ainda, como teste para identificar cruzamentos promissores (MORAES-FERNANDES $\boldsymbol{e t}$ al.,1999).

Contudo, as dificuldades na indução da androgênese em algumas espécies, como as leguminosas, por exemplo, têm limitado sua aplicação nos modernos programas de melhoramento. 
Os mecanismos básicos pelos quais os micrósporos desviam de sua rota ontogenética normal, ainda são pouco compreendidos. Embora as informações, até então obtidas, sejam ainda fragmentadas e difiram de uma espécie para outra, algumas generalizações podem ser feitas.

Tem sido verificado que o estádio de desenvolvimento do micrósporo tem um papel crucial na eficiência da indução haplóide. Tudo indica que, em determinados períodos, o micrósporo apresenta-se mais "suscetível" a alterações em sua via ontogenética e, assim, competente para a androgênese. Em geral este período é anterior à primeira mitose e está relacionado com uma eliminação inadequada de determinantes esporofíticos.

Inúmeras investigações, usando fatores de estresse físicos e químicos, têm mostrado que a resposta androgenética envolve a reorganização do citoesqueleto e a alteração na polaridade dos componentes citoplasmáticos. A expressão de genes de estresse em micrósporos potencialmente embriogênicos sugere que estes estejam relacionados com uma reprogramação celular. Assim sendo, o uso de fatores de estresse parece funcionar como um estímulo-sinal na indução da androgênese.

O conhecimento da complexidade de aspectos celulares, fisiológicos e moleculares que envolvem o processo androgenético ainda é bastante limitado. Estudos multidisciplinares sobre a androgênese serão de fundamental importância não só para a elucidação de muitos questionamentos, como também, para uma efetiva aplicabilidade da cultura de anteras no melhoramento genético vegetal.

\section{REFERÊNCIAS BIBLIOGRÁFICAS}

ATANASSOV, A.; ZAGORSKA, N.; BOYADJIEV, P., et al. In vitro production of haploid plants. World Journal of Microbiology \& Biotechnology, Oxford, v.11, p.400-408, 1995.

BINAROVA, P.; HAUSE, G.; CENKLOVÁ, V., et al. A short severe heat shock is required to induce embryogenesis in late bicellular pollen of Brassica napus L. Sexual Plant Reproduction, Heidelberg, v.10, p.200-208, 1997.

BONET, F.J.; AZBAID, L.; OLMEDILLA, A. Pollen embryogenesis: atavism or totipotency? Protoplasma, Wien, v.202, p.115-121, 1998.

BHOJWANI, S.S.; RAZDAN, M.K. Plant tissue culture: theory and practice. Amsterdam : Elsevier, 1983. 502p.

CAETANO, V.R.; MORAES-FERNANDES, M.I.B. Interdisciplinaridade no CNPT/EMBRAPA: estudos que culminaram com o lançamento, por meio de métodos biotecnológicos, do trigo BR-43. In: ENCONTRO DE
GENETICISTAS DO RIO GRANDE DO SUL, 8, 1992, São Leopoldo, RS. Anais... São Leopoldo : SBG, 1992. p.15-19.

CHEN, C.C.; KASHA, K.J.; MARSOLAIS, A. Segmentation patterns and mechanisms of genome multiplication in cultured microspores of barley. Canadian Journal of Genetics and Cytology., v.26, p.475-483, 1984

CORDEWENER, J.H.G.; HAUSE, G.; GÖRGEN, E., $\boldsymbol{e}$ t al. Changes in synthesis and localization of the $70 \mathrm{kDa}$ class of heat shock proteins accompany the induction of embryogenesis in Brassica napus L. microspores. Planta, Heidelberg, v.196, p.747-755, 1995.

DALE, P. Pollen dimorphism and anther culture in barley. Planta, Heidelberg, v.127, p.213-220, 1975.

FAN, Z.; ARMSTRONG, K.C.; KELLER, W.A. Development of microspores in vivo and in vitro in Brassica napus $\mathrm{L}$. Protoplasma, Wien, v.147, p.191-199, 1988.

GARRIDO, D.; ELLER, N.; HEBERLE.BORS, E. et al. De novo transcription of specific mRNA during the induction of tobacco pollen embryogenesis. Sexual Plant Reproduction , Heidelberg, v.60, p.40-45, 1993.

GRANDO, M.F. Capacidade androgenética e sua relação com o dimorfismo do pólen em linhagens duplo-haplóides de trigo (Triticum aestivum L.) obtidas por cultura de anteras. Porto Alegre, RS, 1989. 186p. Dissertação (Mestrado em Genética) - Curso de Pós-graduação em Genética,Universidade Federal do Rio Grande do Sul, 1989.

GRANDO, M.F.; MORAES-FERNANDES, M.I. Two poit deterministic model for acquisition of in vitro pollen grain androgenetic capacity based on wheat studies. Revista Brasileira de Genetica, Ribeirão Preto, v.20, n.3, p.467-476, 1997.

GUHA, S., MAHESHWARI, S.C. In vitro production of embryos from anthers of Datura. Nature, London, v.204, n. 4957, p.497, 1964.

HEBERLE-BORS, E. In vitro pollen embryogenesis in Nicotiana tabacum $\mathrm{L}$. and its relation to pollen sterility, sex balance and floral induction of pollen donor plants. Planta, Heidelberg, v.156, p.396-401, 1982.

HEBERLE-BORS, E.; REINERT, J. Androgenesis in isolated pollen cultures of Nicotiana tabacum: dependence upon pollen development. Protoplasma, Wien, v.99, p.237-245, 1979.

HEBERLE-BORS, E.; REINERT, J. Isolated pollen cultures and pollen dimorphism. Naturwissenshaften, Heidelberg, v.67, p.311-312, 1980 .

HEBERLE-BORS, E.; REINERT, J. Environmental control and evidence for predetermination of pollen embryogenesis in Nicotiana tabacum pollen. Protoplasma, Wien, v.109, p.249-255, 1981 .

HORNER, M.; MOTT, R.L. The frequency of embryogenic pollen grains is not increased by in vitro anther culture in Nicotiana tabacum. Planta, Heidelberg, v.147, p.156-158, 1979.

HORNER, M.; STREET, H.E. Pollen dimorphism - Origin and significance in pollen plant formation by anther culture. Annals of Botany, v.42, p.771-773, 1978. 
IMMONEN, S.; ROBISON, J. Stress treatments and ficoll for improving green plant regeneration in triticale anther culture. Plant Science, v.150, p.77-84, 2000.

IQBAL, M.C.M.; MÖLLERS, C.; RÖBBELEN, G. Increased embryogenesis after colchicine treatment of microspore cultures of Brassica napus L. Journal of Plant Physiology, Stuttgart, v.143, p.222-226, 1994.

KALTCHUK-SANTOS, E.; BODANESE-ZANETTINI, M.H.; MUNDSTOCK, E. Pollen dimorphism in soybean. Protoplasma, Wien, v.174, p.74-78, 1993.

KALTCHUK-SANTOS, E.; MARIATH, J.E.A.; MUNDSTOCK E., et al Cytological analysis of early microspore divisions and embryo formation in cultured soybean anthers. Protoplasma, Wien, v.49, p.107-115, 1997

KIVIHARJU, E.; PEHU, E. The effect of cold and heat pretreatments on anther culture response of Avena sativa and A.sterilis. Plant Cell, Tissue and Organ Culture, New York, v.54, p.97-104, 1998.

LA COUR, L.F. Nuclear differentiation in the pollen grain. Heredity, v.3, p.319-337, 1949.

MAHESHWARI, S.C.; TYAGI, A.K.; MALHOTRA, K., et al. Induction of haploidy from pollen grains in Angiosperms The current status. Theoretical and Applied Genetics, Berlin, v.58, p.193-206, 1980.

MARDHORST, A.P.; TOONEN, M.A.J.; DE VRIES, S.C. Plan embryogenesis. Critical Reviews in Plant Sciences, v.16, n.6, p.535-576, 1997

MORAES-FERNANDES, M.I.B. Obtenção de plantas haplóides através de cultura de anteras. In: TORRES, A.C.; CALDAS L.S. Técnicas e aplicações da cultura de tecidos de plantas. Brasília : EMBRAPA/ABCTP, 1990. p.311-332.

MORAES-FERNANDES, M.I.B.; STIVAL, A.L.; BRAMMER, S.P., et al. Haplodiploidização: genética e melhoramento. In: TORRES, A.C.; CALDAS, L.S., BUSO, J.A. Cultura de tecidos e transformação genética de plantas. Brasília : EMBRAPA/CBAB, 1999. V.2, p.569-612.

NITSCH, C.; NORREEL, B. Effect d'un choc thermique sur le pouvoir embriogene du pollen de Datura innoxia cultivé dans l'anthere ou isole de l'anthere. Comptes Rendus Hebdomadaires des Seances de l'Academie des Sciences, Série D, v.276, p.303-306, 1973.

NORREEL, B. Étude citologique de l'androgénèse experimentale chez Nicotiana tabacum e Datura innoxia. Bulletin de la Société Botanique de France, v.177, p.461478,1970 .

PENG, M.; ZIAUDDIN, A.; WOLYN, D.J. Development of aspargus microspores in vivo and in vitro is influenced by gametogenic stage and cold treatment. In Vitro Cell Developmental Biology, v.33, p.263-268, 1997.

PETERS, J.A.; BOBROWSKI, V.L.; ROSINHA, G.M.S Produção de haplóides e duplo haplóides. In: TORRES A.C.; CALDAS, L.S.; BUSO, J.A. Cultura de tecidos e transformação genética de plantas. Brasília EMBRAPA/CBAB, 1999. V.2, p.569-612.

RAGHAVAN, V. Origin and development of pollen embryoids and pollen calluses in cultured anther segments of Hyoscyamus niger (henbane). American Journal of Botany, v.65, n.9, p.984-1002, 1978.

RAGHAVAN, V. Developmental strategies of the angiosperm pollen: a biochemical perspective. Cell Differentiation, v.21, p.213-226, 1987.

RASHID, A. Pollen dimorphism in relation to pollen plant formation. Physiologia Plantarum, Copenhagen, v.58, p.544-548, 1983.

RASHID, A.; SIDDIQUI, A.W.; REINERT, J. Ultrastructure of embryogenic pollen of Nicotiana tabacum var. Badisher Burley. Protoplasma, Wien, v.107, p.375-385, 1981.

RASHID, A.; STREET, H.E. Segmentations in microspores of Nicotiana tabacum which lead to embryoid formation in anther cultures. Protoplasma, Wien, v.80, p.323-324, 1974.

REYNOLDS, T.L. Pollen embryogenesis in anther cultures of Solanum carolinense L. Plant Cell Reports, Berlin, v.5, p.273-275, 1986.

REYNOLDS, T.L. A cytological analysis of microspores of Triticum aestivum (Poaceae) during normal ontogeny and induced embryogenic development. American Journal of Botany, v.80, n.5, p.569-576, 1993

REYNOLDS, T.L. Pollen Embryogenesis. Plant Molecular Biology, Dordrecht, v.33, p.1-10, 1997.

SANGWAN, R.S.; CAMEFORT, H. Microsporogenesis in Datura metel L. Ver Cytol Biol Végét Bot, v.5, p.265-282, 1982.

SAX, K. The effect of temperature on nuclear differentiation in microspore development. Journal of Arnold Arber, v.19, p.301-310. 1935 .

SAX, K.; EDMONDS, H.W. Development of male gametophyte in Tradescantia. Botanical Gazette, v.95, p.156-163, 1933.

SMYKAL, P.; PECHAN, P.M. Stress, as assessed by the appearance of sHsp transcripts, is required but not sufficient to initiate androgenesis. Physiologia Plantarum, Copenhagen, v.110, n.1, p.135-143, 2000.

SUNDERLAND, N. Another culture as a means of haploid induction. In: KASHA, K.J. Haploids in higher plants: advance and potential. Guelph : University of Guelph, 1974. p.91-122.

SUNDERLAND, N. Strategies in the improvement of yields in anther culture. In: SYMPOSIUM ON PLANT TISSUE CULTURE, 1978, S.1. Proceedings... Peking : Science 1978. p.65-86.

SUNDERLAND, N.; DUNWELL, J.M. Pathways in pollen embryogenesis. In: STREET, H.E. Tissue culture and plant science. London : Academic, 1974. p.141-167.

SUNDERLAND, N.; ROBERTS, M.; EVANS, L.J., et al. Multicellular pollen formation in cultured barley anthers. I . Independent division of the generative and vegetative cells., v.30, n.119, p.1133-1144, 1979

SUNDERLAND, N.; WICKS, F.M. Cultivation of haploid plants from tabacco pollen. Nature, London, v.224, p.1227-1229, 1969. 
SUNDERLAND, N.; WICKS, F.M. Embryoid formation in pollen grain of Nicotiana tabacum. Journal of Experimental Botany., v.22, n.70, p.213-226, 1971.

SZAKÁCS, E; BARNABÁS, B. The effect of colchicine treatment on microspore division and microspore-derived embryo differentiation in wheat (Triticum aestivum L.) anther culture. Euphytica, Wageningen, v.83, p.209-213, 1995.

TOURAEV, A.; ILHAM, A.; VICENTE, O., $\boldsymbol{e}$ t al. Stressinduced microspore embryogenesis in tobacco: an optimized system for milecular studies. Plant Cell Reports, Berlin, v.15, p.561-565, 1996a.

TOURAEV, A.; PFOSSER, M.; VICENTE, O., et al. E. Stress as a major signal controling the developmental fate of tobacco microspores towards a unified model of induction of microspore/pollen embryogenesis. Planta, Heidelberg, v.200, p.144-152, 1996b.

TOURAEV, A.; VICENTE, O.; HEBERLE-BORS, E. Initiation of microspore embryogenesis by stress. Trends in Plant Science, v.2, n.8, p.297-302, 1997.
ZAKI, M.A.M.; DICKINSON, H.G. Structural changes during the first divisions of embryos resulting from anther and free microspore culture in Brassica napus. Protoplasma, Wien, v.156, p.149-162, 1990.

ZAKI, M.A.M.; DICKINSON, H.G. Microspore derivedembryos in Brassica: the significance of division symmetry in pollen mitosis I to embryogenic development. Sexual Plant Reproduction, Heidelberg, v.4, p.48-55, 1991.

ZAKI, M.A.M.; DICKINSON, H.G. Modification of cell development in vitro: the effect of colchicine on anther and isolated microspore culture in Brassica napus. Plant Cell, Tissue and Organ Culture, New York, v.40, n.3, p.255-270, 1995.

ZÁRSKÝ, V.; GARRIDO, D.; ELLER, N., et al. The expression of a small heat shock gene is activated during induction of tobacco pollen embryogenesis by starvation. Plant Cell Environ., v.18, p.139-147. 1995.

ZHAO, J.P.; SIMMONDS, D.H.; NEWCOMB, W. Induction of embryogenesis with colchicine instead of heat in microspores of Brassica napus L. cv. Topas. Planta, Heidelberg, v.198, p.433-439, 1996. 